\title{
A Risky Enterprise: The Aldine Edition of Galen, the Failures of the Editors, and the Shadow of Erasmus of Rotterdam
}

\author{
Lorenzo Perilli \\ University of Rome Tor Vergata, Italy ${ }^{*}$
}

\begin{abstract}
The Aldine edition of Galen, awaited for more than 25 years, was perhaps the most risky enterprise in the whole history of the publishing house, and it almost brought Aldus' heirs to bankruptcy. Although the editors were among the most renowned specialists of the time, the edition was harshly criticized by one former friend and collaborator of Aldus, Desiderius Erasmus of Rotterdam. Why? Was the edition so bad, were the manuscripts on which the edition was based responsible for its quality? Or were there other reasons for Erasmus' complaint? This paper tries to give some hints in order to answer such questions, arguing that the role of Erasmus in the assessment of the value of the edition should take us into Aldus' house in the period of the late fifteenth and early sixteenth century, and into the political and religious debate of the time.
\end{abstract}

\section{Keywords}

Aldus Manutius, Galen, Erasmus of Rotterdam, Renaissance Venice, ancient Greek medicine, Catholic Church

Published in 1525-1526, the five-volume Aldine edition of Galen in Greek was quickly adopted as authoritative, and was heavily relied on by subsequent editors and translators of Galen's works. ${ }^{1}$ One of the

* University of Rome Tor Vergata, Via Columbia 1, 00133 Rome, Italy (lorenzo. perilli@uniroma2.it).

1) The Venetian edition of Galen has usually been dated to the year 1525. Paul Potter (see $\mathrm{n} .4$ below) has argued that the fifth volume must have been printed in 1526 . The question remains open whether the first four volumes had been circulated in advance, 
rarest of Aldine publications, only two or three complete sets have been sold during the past 30 years. A copy has been auctioned at Christie's in 1999 for 25,836 USD, and an incomplete set including only the first two volumes is currently being offered at 12,500 USD (on J. Norman's History of Science Online Bookshop). A complete set, if such could be found, would probably be worth 50,000 USD or more. It is so rare and consequently so expensive because of the limited number of originally printed copies. Being an exceptional case for Aldus' editions, the initial print run remained the only one. As we shall see, this fact is not without significance.

The development of printed medical books was an important phase in medical history. Aldus Manutius (ca. 1450-1515) in Venice was by far the most important early printer of medical books and classical texts. His most difficult and critical enterprise was the printing of the many works written by Galen. Aldus had planned this edition since his earlier years as a printer on the Campo Sant'Agostin. Galen was an idée fixe for him, one destined to remain an unfulfilled dream during his own lifetime. As early as 1495-his first year of full activity after his first attempts-Aldus mentions his ambition of printing Galen's complete works: dabimus etiam et Hippocratis et Galeni omnia. He does so in the Preface to the second volume of his paramount edition of Aristotle, one of his most ambitious enterprises. He expressed his wish again in the Preface to his Greek Dictionary (Dictionarium Graecum copiosissimum secundum ordinem alphabeti) of that same year: "all that remains of Galen." The Aristotle edition alone, with its 1,800 large-sized pages, contains more text than all of the Latin works printed by Aldus during his 20-year long career. The editio princeps of Galen's works in Greek would have been even bulkier than that of Aristotle and was to mark a new era in both medical and philological scholarship. The five folio volumes were to be printed only ten years after Aldus' death, starting in 1525 , and represent the largest single body of text issued by the Aldine press. ${ }^{2}$

or whether the Aldi awaited the last volume in order to bring the complete set to market.

2) On Aldus' activity and the Venetian environment see Martin Lowry, The World of Aldus Manutius. Business and Scholarship in Renaissance Venice (Oxford, 1979); Giovanni Orlandi, Aldo Manuzio editore, 2 vols. (Milan, 1976); Aldus Manutius and 


\section{The Edition}

Already at the beginning of his activity, Aldus assembled a good number of Greek manuscripts of Galen including his medical, philosophical, and autobi(bli)ographical writings. This alone was a remarkable achievement, if one considers that up to that time only a handful of works had been published in Greek. Many of them were available only in Latin translations, and many more were completely unknown. Other printers attempted such an enterprise before Aldus and failed. Four years earlier Diomedes Bonardus from Brescia edited the Latin Galen for the publisher Filippo Pincio, and complained of the difficulty of finding the necessary manuscripts - and this although copies of the Latin translations of Galen circulated much more widely than Greek antigraphs. The numerous Greek manuscripts collected in Venice and Cardinal Bessarion's library were not yet easily accessible at that time. We learn of loans of Galen's manuscripts from the Biblioteca Marciana starting from 1524 and 1525, when codices containing "Galeni de cena pueri epileptici et alia plura in uno volumine" and "Galeni expositio in librum Hippocratis de acutis egritudinibus," as well as "unum librum graecum in papiro cum cohoperta rubea intitulato (sic) Commentaria Galeni in sextum epidimiarum" are given on loan, the former to Taddeo Contarini on August 1, 1524, the latter to Giambattista Casali (later Bishop in Belluno) on April 27, 1525. ${ }^{3}$

Almost twenty years had elapsed after the first announcement, when Aldus died in 1515 at the age of about 65, before his long-held desire to issue a complete edition of Galen could be fulfilled. His printing

Renaissance Culture, David S. Zeidberg ed. (Florence, 1998); Neri Pozza, "Leditoria veneziana da Giovanni da Spira ad Aldo Manuzio. I centri editoriali di terraferma," in Storia della cultura veneta. Dal primo Quattrocento al Concilio di Trento, vol. 2 (Vicenza, 1980), 215-34. For a stimulating study of ancient texts and their Renaissance readers, see Anthony Grafton, Defenders of the Text: The Tradition of Scholarship in an Age of Science, 1450-1800 (Cambridge, MA, 1991). Older works give valuable information, see Antoine Augustin Renouard, Annales de l'Imprimerie des Alde, ou histoire des trois Manuce et de leurs éditions (Paris, 1834³); Ambroise Firmin-Didot, Alde Manuce et l'Hellenisme à Venise (Paris, 1875); Domenico Bernoni, Dei Torresani, Blado e Regazzoni, celebri stampatori a Venezia e Roma nel XV e XVI secolo (Milan, 1890).

3) See Giulio Coggiola, "Il prestito di manoscritti della Marciana dal 1474 al 1527," Zentralblatt für Bibliothekswesen, 25 (1908), 47-70, see 54f, also 66; 67f. 
activity passed into the hands of his father-in-law Andreas Asulanus, who continued Aldus's scholarly tradition bringing out a number of Greek literary and historical editiones principes with the help of his sons. But whereas the family's not unlimited linguistic expertise might have sufficed to produce reliable editions of geographers and poets, it was clearly not up to the challenge that Galen's works presented. To meet this challenge, the professor of medicine Giambattista Opizzoni (ca. 1485-ca. 1532) was put in charge of a large group of assistants recruited mainly from among northern medical scholars then active or studying in Italy: John Clement (ca. 1495-1572), Edward Wotton (1492-1555), William Rose (ca. 1490-1525), and Thomas Lupset (1495-1530)_all English followers of the famous Oxford Humanist Thomas Linacre (ca. 1460-1524) —as well as the Saxon scholar and scientist Georg Agricola (1495-1555). An international team had to be recruited and was in charge of that thorny edition.

The significance of the first printing of an author such as Galen cannot be overestimated. His works were not to be found in a single or even a small number of manuscripts, but had to be pieced together from as many manuscripts as the printing house could lay its hands on. ${ }^{4}$

\section{Erasmus' First Reaction}

How eagerly this edition was expected by the scholarly world is attested to by a letter of Desiderius Erasmus of Rotterdam (1466 or 1469-1536)

\footnotetext{
4) On Galen's Aldina and related topics see Nikolaus Mani, "Die griechische Editio princeps des Galenos (1525), ihre Entstehung und ihre Wirkung," Gesnerus, 13 (1956), 29-52; Vivian Nutton, John Caius and the Manuscripts of Galen (Cambridge, 1987) and "John Caius and the Linacre Tradition," Medical History, 23 (1979), 373-91; also Jutta Kollesch, "René Chartier als Herausgeber der Werke Galens" in Antiquitas GraecoRomana ac tempora nostra, Jan Burian and Ladislav Vidman, eds. (Prague, 1968), 525-30, and Paul Potter, "The editiones principes of Hippocrates and Galen and their Relationship," in Text and Tradition: Studies in Ancient Medicine and its Transmission, presented to Jutta Kollesch, Klaus-Dietrich Fischer, Diethard Nickel, Paul Potter eds. (Leiden, 1998), 243-61. Information on early printed editions and translations of Galen's works are in Richard Durling, "A Chronological Census of Renaissance Editions and Translations of Galen" Journal of the Warburg and Courtauld Institutes, 24 (1961), 230-99.
} 
dated October 5, 1525, in which we are informed that Galenus vehementer expectatur ab eruditis ("scholars are waiting impatiently for Galen"). ${ }^{5}$ Erasmus had been interested in medical authors since the very first years of his career, and he mentions medical books even in his first letter to Aldus, at a time when they still did not know each other personally, in 1507. The edition of Galen is mentioned in many of Erasmus' letters, thus giving us a picture drawn by a contemporary. Here is a sample as assembled by Paul Potter: ${ }^{6}$

5 October 1525

17 January 1526

28 April 1526

6 May 1526

16 May 1526

\section{Galenus vehementer expectatur ab eruditis}

Scholars are waiting impatiently for Galen.

Et Aldinae quidem officinae non omnino maligne respondit publicus orbis fauor, quae praeter tot egregios scriptores nunc nobis parturit omneis Galeni libros Graecos

Not at all bad are the reactions of the public towards the Aldine press, which besides so many excellent writers now gives birth to the complete Greek works of Galen for us.

Prodiit totus Galenus sua lingua nobis loquens

The complete Galen has appeared speaking to us in his own language.

Verti Latine priores aliquot paginas in Galeno

I have translated some of the first pages of the Galen into Latin.

Mitto ad te praeludium Galeni, qui totus Graecus prodiit ex Aldi officina

I am sending you a first taste of Galen, who has appeared complete in Greek from the Aldine press.

Already in April 1526 Erasmus had received a copy of the five volumes as a gift from the printer. The gift was one of unusual generosity. The edition was perhaps the most expensive in the whole catalogue, the price was "incredibly high," as is confirmed once again by a later letter of Erasmus, who in 1533 writes that the unbound edition of Galen could be purchased at 30 golden florins, "however incredible this may sound": hoc ne videatur incredibile, solus Galenus, quem mihi dono misit

5) Erasmus' letters are edited in Opus epistolarum Desiderii Erasmi, ed. Percy Stafford Allen, 12 vols. (Oxford 1906-1958).

6) Potter, "The editiones principes," 260. 
Franciscus Asulanus, hic nudus et crudus vendebatur triginta florenis aureis. ${ }^{7}$

However, the first hint at the humanist's unexpected reaction to the edition comes from the fact that, for a long interval, Erasmus did not even answer the Venetian printers after receiving the five volumes, nor did he express his gratitude. He took his time, browsing through the volumes and working at the translation of the first three treatises. Finally, more than five months later, in September, Erasmus writes to Francis Asulanus to express thanks for the gift:

3 Sept. 1526: Nothing more pleasant, my dearest Franciscus, has happened to me in a long time, than your sending me the complete Galen as a present. ... But the greatest pleasure I have received from your heart to me, still mindful of the ancient friendship, even more than from the gift itself ... If my heart does not deceive me, this edition will achieve no little fame and gain for you. No fear of competitors; while there might be someone who wants to, no one could. ${ }^{8}$

Although written later than expected, this statement reflects the high esteem in which Erasmus seems to hold the Venetian edition of Galen's works, as is also apparent from the testimonies quoted so far.

By this time, Erasmus had already translated the first treatises, and we must therefore assume that he knew the work. Moreover, he probably had already browsed through the whole edition in search of material to be added to his collection of proverbs, the famous Adagia (or Adages), a task he was to accomplish by 1528 . The results of this selection can still be seen from the remarks he made in the margins and between the lines of his own copy (ff. Ir-5v). The Aldine Galen that Erasmus owned has been rediscovered in the Provinciale Bibliotheek van Friesland (now part of Tresoar) in the Netherlands, the discovery being announced in 1983 in the newsletter Erasmus in English published

\footnotetext{
7) Erasmus, Epist. 2780, March 1533, in Allen, ed., Opus epistolarum Desiderii Erasmi, 10: 179 .

8) Erasmus, Epist. 1526, in Allen, ed., Opus epistolarum Desiderii Erasmi, 6: 305-6: "Nihil iam diu nobis accidit, Francisce chariss., iucundius quam quod totus Galenus ad nos venit ex tua munificentia. ... Tamen hic mihi plus voluptatis attulit animus in me tuus, etiamnum memor veteris amicitiae, quam vel donum ipsum ... Aut me fallit animi praesagium, aut haec aeditio conciliabit tibi non parum et nominis et compendii. Aemulos non est quod verearis: vt sit hic qui velit, non est qui possit."
} 


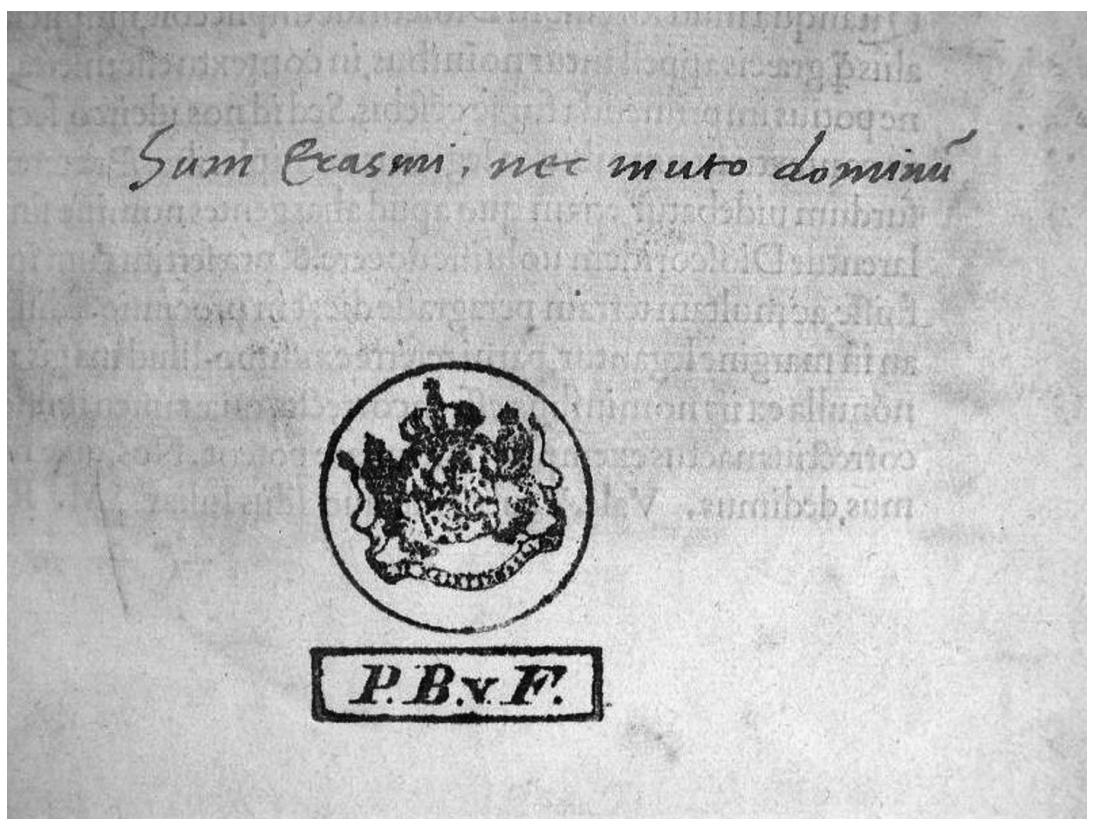

Figure 1: Owner's entry in Erasmus' copy of several Aldine editions: "I am the property of Erasmus, and will not change my owner" (Sum Erasmi, nec muto dominum). (Photo: Tresoar, Leeuwarden)

by the University of Toronto Press. ${ }^{9}$ Among the five Aldinae of Erasmus in the same library, the copy of Galen is the only one which does not have the typical owner's entry (see fig. 1 ). ${ }^{10}$

9) Martin H.H. Engels, "Erasmiana in the old University Library of Franeker," in Erasmus in English, 12 (1983), 19-20.

10) On Erasmus' books and the rediscovery of his copy of the Aldine Galen see the works of the former Librarian of the Tresoar, Martin H.H. Engels, Catalogus van werken door Erasmus van Rotterdam geschreven of uitgegeven, aanwezig in de Provinciale Bibliotheek van Friesland (Leeuwarden, 1986); Martin H.H. Engels, Erasmus' handexemplaren: vijf Griekse Aldijnen in de Franeker collectie van de Provinciale Bibliotheek van Friesland [Tresoar] te Leeuwarden (Leeuwarden, 1994); Martin H.H. Engels, Auteurs in de bibliotheek van Erasmus. De zogenaamde verzendlijst op persoonsnamen (Leeuwarden, 1997). 


\section{Erasmus, Two Years Later}

All the more surprising, therefore, is what we read in a letter written by Erasmus exactly two years later and addressed to a young scholar, Joachim Martens, who was himself an expert of Galen and had translated one of his works into Latin. With the Aldine edition of Galen in mind, Erasmus writes as follows:

16 Sept. 1528: It is a torture, such a great author so badly edited, and at so high a cost. But this is the quality of what nowadays reaches us from Italy. And all this for greed! A sacrilege, for just a few coins, which could rather be used to pay a good corrector. ${ }^{11}$

How should we reconcile Erasmus' enthusiasm of 1526 and his prediction of a great success with the harsh judgment of 1528? It should be pointed out, first of all, that this change of mind was not due to a deeper and more careful examination of the work. Indeed, soon after having received the books, and long before writing to the printer to acknowledge receipt of the gift and to express his gratitude, in May 1526, Erasmus had already torn the edition apart with his criticism expressed in letters to his friends.

We have already mentioned the letter in which Erasmus said he had translated the first few pages of Galen. ${ }^{12}$ This same letter, of 6 May 1526, goes on as follows:

I've never seen anything more corrupt. This is something that makes me suffer for three reasons: for the scholars, for such a great author, and finally for Asulanus

11) Erasmus, Epist. 1707, in Allen, ed., Opus epistolarum Desiderii Erasmi, 6: 336-37. "Discrucior tantum auctorem tantis impendiis tam mendose proditum, qualia fere sunt quae nobis prodeunt ex Italia. Vide quod faciat auri sacra fames! Quantum sacrilegium committitur ob pauculos aureolos, quibus conduci poterat eruditus castigator!"

12) On Erasmus as a translator of Galen, see Leo Elaut, "Érasme, traducteur de Galien," Bibliothèque d'Humanisme et Renaissance, 20 (1958), 36-43; Erika Rummel, Erasmus as a Translator of the Classics (Toronto, 1985); Bunna Ebels-Hoving and Ebel Johan Ebels, "Erasmus and Galen," in Erasmus of Rotterdam. The Man and the Scholar. Proceedings of the Symposium Held at the Erasmus University, Rotterdam, 9-11 November 1986, Jan Sperna Weiland and Willem. Th. Frijhoff, eds. (Leiden, 1988), 132-42. 
himself ... The one who was in charge of the correction seems not to have been familiar even with the basics of Greek language. ${ }^{13}$

Elsewhere, Erasmus defines his translation as rather a work of divination, and in a letter he remarks:

I send to you the first part of Galen, whose complete Greek text has appeared in Aldus' printing house, translated by us; check it, and judge whether we were right in our guesses. Since guessing is what was needed: I have never seen anything worse. $^{14}$

"I have never seen anything worse": A severe judgment indeed. But how, then, could Erasmus say a few months later, while writing to Francis Asulanus, that haec aeditio conciliabit tibi non parum et nominis et compendii ("this edition will make you rich and famous")?

\section{A Difficult Task, an Expensive Edition}

The edition had undoubtedly been a difficult task, and no doubt it is faulty in many respects. But then, the Greek Aristotle, too, as well as the Dioscorides, turned out to be rich in errors. ${ }^{15}$ The Galen edition was based at least in part on manuscripts that are difficult to decipher. An example is the famous Laurentianus graecus 74,3 , which contains plenty of abbreviations, sigla, and omissions of endings, so that the reader is invited to reconstruct, rather than read, the original text (see fig. 2). The Galen edition was not the best among the Aldine editions;

13) Erasmus, Epist. 1707, in Allen, ed., Opus epistolarum Desiderii Erasmi, 6: 336-37: "Nihil comperi mendosius. Quae res animum meum triplici nomine discruciat, et studiosorum, et tanti autoris, denique et ipsius Asulani, ... Qui praefuit emendationi, videtur vix satis tenuisse prima Graeci sermonis elementa."

14) Erasmus, Epist. 1713, in Allen, ed., Opus epistolarum Desiderii Erasmi, 6: 34546: "Mitto ad te praeludium Galeni, qui totus Graecus prodiit ex Aldi officina, versum a nobis; conferes et iudicabis nuncubi recte diuinauerimus. Nam plane diuinandum erat: nihil adhuc vidi deprauatius."

15) On Aldus' editions of Aristotle and other Greek authors see the works of Martin Sicherl, Handschriftliche Vorlagen der Editio Princeps des Aristoteles (Mainz, 1976) and Griechische Erstausgaben des Aldus Manutius (Paderborn, 1997). 


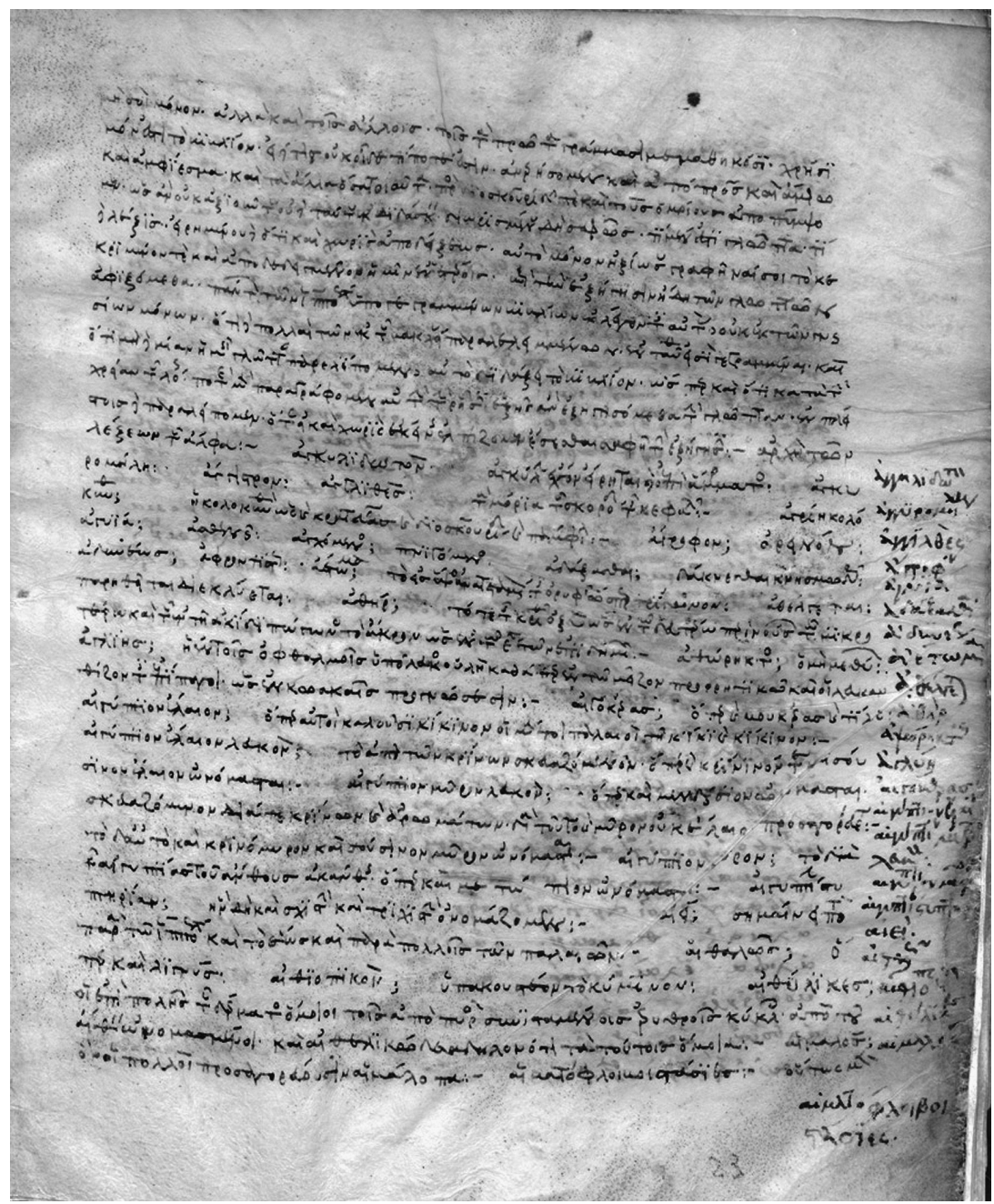

Figure 2: The thirteenth-century Codex Laurentianus graecus plut. 74.3, fol. 23r (Galen's Hippocratic Glossary). (Photo: Biblioteca Medicea Laurenziana, http://teca. bmlonline.it)

but it was also the most difficult, as can be gauged by the 30 years that elapsed before its completion.

As mentioned earlier, the significance of the first printed edition of Galen's text in Greek could scarcely be overestimated. Only three of his treatises had been published in Greek before: 106 were printed in the 
Aldine edition. As we learn from Erasmus, the edition was feverishly awaited, and its resonance among scholars was great. The same cannot be said of its circulation: the product did not sell very easily.

The price of Aldine editions was usually higher, often much higher, than the price of books from other printers. ${ }^{16}$ The Galen edition was even more expensive and therefore easily beyond the financial capacity of possible buyers, for instance of physicians. Besides, most physicians and medical practitioners would have been unfamiliar with the Greek language. Moreover, criticism, as in the case of Erasmus, and also insincere criticism, began to spread. This edition became one of the most risky enterprise of the whole history of the press. As has been said at the beginning of this paper, it was never reprinted, and this was unusual for Aldus and his heirs. By contrast, the edition of the Latin Galen was the most successful for the rival press of the Giunta: eleven reprints of the work were made, and it has been judged one of the main commercial speculations of the Giuntina publishing house in Venice. ${ }^{17}$ The Giunta edition had at least two advantages: a low price, as was usual for these editions; and the language, since Latin was by far more accessible than Greek.

\section{Erasmus' Criticism and his Inconstant Relationship to Aldus and his Heirs}

We may now return to Erasmus' harsh judgment of the editors, which is beyond all expectations. He says that the person in charge of the correction was unaware of Greek, vix satis tenuisse prima Graeci sermonis elementa (Epist. 1707). Yet Erasmus knew that the final revision and correction of the work had been assigned to his young German friend and admirer Georg Agricola. Erasmus had been so informed in August 1525, when the edition was almost finished, by Leonard Casembroot, who wrote to him: "Georg Agricola, a young admirer of yours, also

16) On this see Klaus Wagner, "Aldo Manuzio e i prezzi dei suoi libri," La biblioflia, 77 (1975), 77-82; Pietro Silverio Leicht, "I prezzi delle edizioni aldine del '500," Il libro e la stampa, 6,3 (1912), 74-84.

17) See Antoine Augustin Renouard, "Notice sur la famille des Junte," in Annales de l'imprimerie des Aldes (Paris, 1834), VII; Paolo Camerini, Annali dei Giunti, I 1-2 (Florence, 1963). 
greets you; he is responsible for the correction of Galen for the Asolanus." ${ }^{18}$ For the same publisher, Agricola was also to edit the works of Hippocrates in 1526. A few years later, Erasmus was to write a commendatory Preface for Agricola's Bermannus sive De re metallica, ${ }^{19}$ and would always have a positive opinion of this younger scholar. Among the other editors was his good friend Thomas Lupset, whom Erasmus loved "as a son" (quem semper filii loco dilexi), and who was, in turn, a friend of one of Erasmus' best friends, Thomas Linacre ("a man of incomparable learning," according to Erasmus' Adagia 4552). Finally, the person responsible for the whole team was the physician Giovan Battista Opizzoni, professor of medicine in Pavia, also a friend of Erasmus, who had entrusted him with the manuscript of the new edition of his Adagia at a time when the Asolani refused to print it, so that he would persuade the publishers.

In short, one may say that the Galen edition was, in effect, created within Erasmus' circle. Were his letters unavailable, nobody could therefore have expected his harsh judgment of that edition.

But there is more. Many years after his stay in Venice in 1508, and a few years after the publication of the Galen edition, Erasmus wrote one of his last Colloquia in 1531, in which he recalls his stay with Aldus. The Dutch humanist spent eight months in his house on the Campo Sant'Agostin when he first came to meet the famous printer. We must assume that he had good reasons for choosing this topic for a work written 24 years after the event. The title is significant: Opulentia sordida, "Sordid wealth," and gives us a clear idea of what to expect. ${ }^{20} 1531$ was the year in which Erasmus had been attacked by Julius Caesar Scaliger, who had said - and he was not alone in asserting this- that according to reliable sources Erasmus had been in Venice not as a guest of Aldus, but as one of his employees, and one "who used to drink for three, and to work for half a man." 21

\footnotetext{
18) Epist. 1594, in Allen, ed., Opus epistolarum Desiderii Erasmi, 6: 142: "Salutat quoque et Georgius Agricola, iuuenis tui nominis studiosus cum primis: is est praefectus castigando Galeno apud Azula $<$ nu $>$ m.”

19) See Georg Agricola, Bermannus (Le mineur): Un dialogue sur les mines, ed. Robert Halleux and Albert Yans (Paris, 1990).

20) See Manlio Dazzi, Aldo Manuzio e il dialogo veneziano di Erasmo (Vicenza, 1969).

21) Julius Caesar Scaliger, Oratio pro Cicerone contra Erasmum (Paris 1531), 320: “Tu
} 
In his small work of 1531, Erasmus is indeed sarcastic in describing the meager life in the printing house, and his attacks are directed mostly against Andreas Asulanus, whose name also stands in the title-page of the Galen edition. Erasmus describes the poverty in which he had to live, of wine diluted with water, the sort of liquid that "I do not know for what reason they call soup," cheese which was "as hard as stone," rotten eggs, small mollusks coming from the public lavatories, and so on. Nor was there enough time for breakfast or dinner. Italians, says Erasmus, do not care for breakfast at all, while Germans need at least one hour for breakfast, and two hours for dinner; Italians prefer money to pleasure, pecuniam malunt quam uoluptatem. ${ }^{22}$

Indeed, it is not unlikely that Erasmus, while in Venice, was paid for his work as a press-corrector or proof-reader. In his letters we also find some hints concerning the fact that he had been paid by Aldus for correcting the position of the verses of Plautus' comedies. At that time Erasmus was not well-off. His family was not wealthy, he was orphaned as a teenager, and for many years he had to look after his economic interests. After leaving Venice, he spent several years in Oxford and Cambridge, where he became a sort of public beggar who repeatedly asked his friends and patrons for help and money. ${ }^{23}$ He went to England because "mountains of gold" had been promised to him. ${ }^{24} \mathrm{He}$ expected

cum semihominis operam in Aldi officina legendo praestares, potando autem tergeminus Geryon esse."

22) Erasmus, "Opulentia sordida", in Opera Omnia Desiderii Erasmi Roterodami recognita et adnotatione critica instructa notisque illustrata, I/3 (Colloquia), edd. L.-E. Halkin-F. Bierlaire-R. Hoven, Amsterdam 1972, 681-685: "ex phialis vini aquaeque (...), iusculum, quod illi, nescio quam ob caussam, appellant ministram (...), caseus ille saxeus, (...) ova tria (...) semiputria, (...) concharum minutum genus (...) potissimum e latrinis (...). At Germanis vix sufficit hora in ientaculum, tantundem in merendam, sesquihora in prandium, duae horae in coenam (...). Suus cuique genti mos est. Itali minimum impendunt gulae; pecuniam malunt quam voluptatem."

23) See e.g. Silvana Seidel Menchi, Introduzione, in Erasmo da Rotterdam, Adagia. Sei saggi politici in forma di proverbi (Turin, 1980), xxvii. On Erasmus in England, see also Maurice Pollet, "Érasme en Angleterre," in Colloquia Erasmiana Turonensia I (Toronto, 1972), 161-74.

24) Responsio ad Petri Cursii defensionem (1535) = Epist. 3032, in Allen, ed., Opus epistolarum Desiderii Erasmi, 11: 177: "nisi promissis montibus aureis in Angliam fuissem retractus verius quam reuocatus." 
a paradise of arts and culture in which he would be adequately appreciated; but he incessantly asks for money, and his powerful friends often respond coldly, humiliating him. Lord Mountjoy, one of those who had insisted on having Erasmus in England, eventually refused to give him what he asked for, and their relationship became one of mutual impudence. ${ }^{25}$ Even a good friend of his, Thomas Linacre, advises him not to insist and considers his behavior shameless. Erasmus explains that he is in extreme poverty (in summa versatur inopia), to which his friends respond by inviting him to beg more humbly (si humiliter mendicaveris).

Who was right? Erasmus, who claimed that he needed money while living in poverty, or his patrons and friends, who considered his continuous begging to be immoderate? There is testimony which can be of some help to settle this issue. An official document from the University of Cambridge states that in 1513 Erasmus received a huge salary, immensum stipendium est quod preceptori Greco sumus polliciti, to the point that the university was no longer able to pay it unless Lord Mountjoy (who had been a pupil of Erasmus) offered his assistance. Otherwise, the University would have to dismiss Erasmus from teaching Greek, litterarum Graecarum iactura faciunda. ${ }^{26}$

In this light, it is all the more surprising what Erasmus says of his teaching in Cambridge and Oxford in 1514:

There are two universities here, Oxford and Cambridge, and both of them want to have me. In Cambridge I have been teaching Greek and the sacred script for several months, but gratis, and it has been decided that so it should always be. ${ }^{27}$

25) Erasmus, Epist. 237, in Allen, ed., Opus epistolarum Desiderii Erasmi, 1: 18: “impudenter rogantem impudentius reppulit."

26) Gt. Britain-Public Record Office: State Papers, Henry VIII, $₫ 5$, f. 21 (in Letters and Papers Foreign and Domestic of the Reign of Henry VIII [London, 1862], vol. I, John Sherren Brewer, ed., doc. 4428); also in the Appendix X to volume I of Erasmus' Letters edited by Allen. That the letter was written by the Offices of Cambridge University is Brewer's conclusion, which Allen shares and considers well-grounded.

27) Erasmus, Epist. 233, in Allen, Opus epistolarum Desiderii Erasmi, ed., I: 473: "Sunt hic duae uniuersitates, Oxonia et Cantabrigia, quarum utraque ambit habere me; nam Cantabrigiae menses complures docui Graecas et sacras litteras, sed gratis, et ita facere semper decretum est." 
Gratis? According to Venn's Alumni Cantabrigenses, Erasmus was at the same time Lady Margaret Professor of Theology in Cambridge from 1511 to $1515 .^{28}$

In the years to come, Erasmus would enjoy an increasing success. As far as the earlier years are concerned, however, he displayed the frailty of someone who, relying only on himself, still had to find his way. In addition, he became increasingly excluded from Italy, in spite of his friendly relationship with the Pope Leo II. ${ }^{29}$

This situation is mirrored in the relationship of Erasmus with the heirs of Aldus, Andreas and Francis Asulanus, and Paul Manutius. Because of the increasingly difficult relations between Erasmus and the Church of Rome, leading to the ban of Erasmus' works, including at a later stage all the Colloquia, and because of the will of Aldus' heirs not to be involved in such a treacherous web, the situation eventually reached the point where several years later the name of Erasmus was deleted from the catalogues of the publishing house and from the front page of the reprints of his works, and replaced by the neutral yet perhaps insulting formula of "Batavus (or Transalpinus) quidam homo" ("a certain Batavian [or Transalpine] man"). True, this was due rather to the increasing intensity of the dispute between Erasmus and the Church, of which the peak was reached after Erasmus' death. However, already in 1522 some works of his are accused of being against morality. Subsequently, his writings began to be forbidden, some in 1526 at the Sorbonne in Paris, and finally the Adagia and all other works by the Index librorum prohibitorum, the Index of Forbidden Books, in 1559. Indeed, Erasmus' name was placed in the category of the Auctores quorum libri et scripta omnia prohibentur, and, to leave no doubt, cum universis Commentariis, Annotationibus, Scholiis, Dialogis, Epistolis, Censuris, Versionibus, Libris et Scriptis suis, etiam si nil penitus contra Religionem, vel de Religione contineant. ${ }^{30}$ In this situation, Aldus' heirs chose

\footnotetext{
28) See John and John Archibald Venn, Alumni Cantabrigienses. A Biographical List of All Known Students, Graduates and Holders of Office at the University of Cambridge, from the Earliest Times to 1900, 10 vols. (Cambridge, 1922-1958), vol. 2 (1922).

29) On Erasmus in Italy, see Augustin Renaudet, Erasme et l'Italie (Geneva, 1954); Léon-Ernest Halkin, "Érasme en Italie," in Colloquia Erasmiana Turonensia I (Toronto, 1972), 37-53.

30) Cf. George Haven Putnam, Censorship of the Church of Rome and Its Influence upon
} 
to be careful. Still, the deletion of Erasmus' name from the catalogues of the Venetian press has a bitter taste, and can be considered as the symbol of an increasing wearing out of their relationship. As we shall see, the conflict with the Church played a definite role also concerning Erasmus' judgment of the edition of Galen.

\section{Erasmus, Aldus, Froben: A Controversial Story}

Something else happened in 1520 between Erasmus and the Italian printers, which is important to his reception of the Galen edition. At the time, a new edition of the Adagia was printed in Venice. It was just a commercial business enterprise, to be explained by Erasmus' fame. In fact, the edition was not authorized. It was a reprint of the Froben edition of 1515. Worse yet, Francis Asulanus wrote in his Preface that the text printed by Froben and authorized by Erasmus was imperfect, faulty, and affected by so many mistakes as to offend the reader. Only now, thanks to his own new edition, had the text been perfected and restored. The polemic was manifestly against Froben, but it also affected Erasmus.

The story goes back to as early as 1508 , to the beginning of the relationship between Erasmus and Aldus. Aldus printed the Adagia on Erasmus' insistence; the publication was a great success. Its success far exceeded that of the earlier editions, which had appeared between 1500 and 1506 in Paris by the French printer Josse Bade and in Strasbourg by the Alsatian printer Matthias Schürer. Erasmus had found in Venice not only an excellent printer, but also the rare possibility of accessing a library whose boundary, as he put it, was the world. And lots of unpublished Greek manuscripts, from which the "Batavus homo" could draw unexplored material for his selection of proverbs.

the Production and Distribution of Literature. Part I (New York \& London, 1907 [repr. 2003]), 335. On the Colloquia and their ban from 1524 onward, see, e.g., Franz Bierlaire, Le Colloques d'Erasme: réforme des études, réforme des moeurs et réforme de l'Eglise au XVIe siècle (Paris, 1978), 142-43; on the removal of Erasmus' name, see $145 \mathrm{n} 2$ and 302. On the removal of his name from title pages, see also Karol Glombiowski, "Über die Verbreitung der Schriften des Erasmus von Rotterdam in Schlesien in der Zeit der Renaissance," in Kwartalnik Historii Nauki i Techniki, 5 (1960), 12552 , at 145 . 
But no sooner had this edition become available than Froben published an unauthorized reprint. Aldus had granted no permission. But had Erasmus? We do not know. But one can imagine that Erasmus was not displeased by this competition surrounding his writings, as he had fully understood the power of printing. Aldus, however, was not happy at all about this development. Erasmus went from Froben to Aldus and from Aldus back to Froben. From the complete catalogue of all the editions of his works, we can see how he tried to have the same work reprinted as often as possible, sometimes with new prefaces, sometimes in identical form, up to 1520 . In the case at issue, then, the Asolani had decided to reprint a Froben edition that had already appeared in Basel. Froben in turn reprinted it again in 1522. Francis Asulanus thereupon wrote to Erasmus in protest against this and against his attitude. Erasmus denied the charge of conspiring with Froben and tried to convince Asulanus that everything was fine, adding: "If you agree I'll send you a new text of the Adagia, on condition that it be printed within a few months." The text was sent, but months went by with no trace of the promised edition. One year after, as there were still no news, Erasmus wrote: "If you do not need the text I sent, please do send it back to me. I'll pay for the shipping cost (...). And there is always a typographer, ready to print it." ${ }^{31}$ We are now in August 1525. Erasmus' letter reaches Venice in the same period that the Galen edition was being printed, the fourth volume being ready by then.

A few months later, Francis Asulanus sent the courtesy copy of his costly Galen edition to Erasmus. As we have seen, Erasmus did at first not answer, translated the first treatises, wrote about the edition to his friends, and only months later wrote to Asulanus to thank him for the gift. But in that same year 1526, he also had to give up the idea of printing his Adagia in Venice and, although he considered the Venetian press to be much better than any other, he had to content himself once again with Froben, who reprinted the work in 1526.

These circumstances put us in a much better position to understand some of the reasons for Erasmus' moody feelings about the Aldine

31) Erasmus, Epist. 1592, in Allen, ed., Opus epistolarum Desiderii Erasmi, 6: 133: "Si non est e re vestra, redeat exemplar, absque sumptu vestro; quod tamen meo sumptu misi (...). Et semper paratus est typographus". 
House, which presumably affected also his judgment about their edition of Galen's works.

But this is not yet the whole story. Léon E. Halkin, an authority on Erasmus, once made a decisive remark concerning the double register of Erasmus' immense correspondence: "by means of his accurately selected letters, Erasmus wants to leave the image he has chosen of himself, but the answers of his interlocutors suggest continual adjustments to this image." ${ }^{32}$ His attitude towards the production of the Venetian printers had indeed changed. The register of his private correspondence with his friends differed from that of the more formal letters he exchanged with the Asolani. Behind the curtain of affected benevolence which Erasmus chose for his relations with the printers, a rather different picture emerges.

By 1525, Erasmus had for a long time insisted that his work be printed in Venice. To further this objective, he had asked his friends to investigate what was going on among the Asulani, looking for help. Among these friends was Thomas Lupset, since 1523 a member of the team in charge of the Galen edition. At the end of August 1525, when at least the first four volumes of the Galen edition had been printed, Lupset wrote to Erasmus: "I should write much about the shameful manners of Francis Asulanus towards you." 33

The same day, another letter was written to Erasmus by Leonard Casembroot, son of an illustrious family and soon to be appointed Burgomeister of Bruges. Casembroot reports on his attempts in Venice on behalf of Erasmus to further the printing of a new edition of the Adagia (which Erasmus unceasingly enlarged and improved), narrating that Asulanus, when he knows that somebody wants to talk to him about Erasmus, shamefully pretends not to be at home, although his voice can be heard from outside. ${ }^{34}$ Finally, Asulanus is tired of Eramus'

\footnotetext{
32) "Erasme éditeur de sa correspondance. Le cas de l' "Auctarium»," Bibliothèque d'Humanisme et Renaissance, 40 (1978), 239-47, at 239.

33) Epist. 1595 (23 August 1525), in Allen, ed., Opus epistolarum Desiderii Erasmi, 6: 143 "de Francisci Asulani indignis adversus te moribus multa mihi forent scribenda." 34) Epist. 1594 (23 August 1525), in Allen, ed., Opus epistolarum Desiderii Erasmi, 6: 139 "Azulana illa (Azinina fere dixissem) par impudentiae perfidia!, nos identidem recursantes fallere, atque ideo subinde negare domi praesentiam suam, quamquam vocis indicio (ecce frontem!) interim proditam.”
} 
friends incessantly knocking on his door, and with a contemptuous attitude answers to them: "Get out of the way! I have known Erasmus for many years; he is such a good friend and well known to me. I shall abundantly satisfy him!"35 Did he maybe attempt to grant satisfaction by sending him the costly Galen edition?

\section{The Role of Religion and Politics}

One more element is needed in order to complete our picture. Many motives are involved in Erasmus' criticism of the Greek Aldine edition of Galen. These do not so much have to do with contents, manuscripts and mistakes, but rather with personal dislike and rivalry, and also with an ongoing political and religious clash in which Erasmus was one of the main figures. ${ }^{36}$ Martin Luther had erupted on the scene in the same years, his 95 Theses having being affixed to the Wittenberg church gate in 1517. While Erasmus seemed to agree with him on a number of topics and Luther was viewed as an Erasmian by some, their views were soon to enter into conflict. In any case, the Church of Rome looked unfavorably upon both of them. On June 15, 1520, in the Papal Bull "Exsurge Domine," Luther's works were prohibited. One year later, on June 12, 1521, his works were burned in Rome, and he himself is condemned in effigie, in his absence. In the following years, has we have seen, Erasmus' works began to be forbidden, and his entire oeuvre was bound to the Index.

In this context, we should look at the fourth volume of Aldus' Galen: it is perhaps no coincidence that it is dedicated to the famous papal official Girolamo Aleandro. Born in 1480, Aleandro had reached Venice a few days after Erasmus and had entered Aldus' circle. In Venice, he lived in the same house as Erasmus and Aldus for five months, and shared with the latter not only the same room, but also the same bed. ${ }^{37}$ He helped Erasmus with the Adagia, reminded him of Michele

\footnotetext{
35) Ibid., 140: "superciliose nos contemnit, et lacessitus respondet, 'Abite vos! Satisfaciam abunde Erasmo', ... tam mihi a multis annis familiari, tam amico, tam noto." 36) On a kind of religious community shared by Erasmus and other men of letters, see Constance M. Furey, Erasmus, Contarini, and the Religious Republic of Letters (Cambridge/New York, 2006).

37) See Erasmus, Epist. 2443, in Allen, ed., Opus epistolarum Desiderii Erasmi, 9: 164:
} 
Apostolio's collection of proverbs-he proved himself to be a man of learning. In 1519, he became librarian at the Vatican Library, and later, as the importance of his functions increased, he was appointed Special Inquisitor, and in this capacity had to carry out Luther's excommunication. In fact, he even attempted to persuade Emperor Charles V to kill him.

In 1525, the year when the Galen edition was published, Aleandro was appointed Apostolic Nuncio to the Court of the King of France. However, he found the time, and must have had good reasons to do so, to write a violent personal attack against Erasmus entitled Racha - the title referring to a Hebrew word that, according to Aleandro, Erasmus had misinterpreted in his commentary to the Gospels. In accordance with Augustine's Sermon on the Mount 9,23, this word meant "the feeling of an indignant soul." Although Aleandro's work was not published, Erasmus knew and read it. ${ }^{38}$ The power of Aleandro continued to increase, as did his anti-Lutheran and anti-heretical activities. And he did not look favorably upon the exchange of letters between Erasmus and Luther. While, until 1518, the relationship between Erasmus and Aleandro had been relatively smooth, Aleandro now reported Erasmus' "crimes" to Pope Giulio de' Medici (Clement VII). Aleandro's charges against Erasmus reverberated in many treatises written in Italy between 1524 and 1534. Aware of this, Erasmus held Aleandro responsible for the burning of books that took place in the Netherlands. The two men wrote and published against each other, not without intermittent but unsuccessful attempts at a reconciliation. Significantly enough, a few years later, Erasmus was to depict Aleandro in the already mentioned Dialogue Opulentia sordida, calling him "Verpius," "the circumcised," turning him into a Jew (which he was not) - a charge that he repeats in his letters, thereby formulating a terrible offence to the Inquisitor of the Church of Rome in charge of fighting against Luther. ${ }^{39}$

\footnotetext{
"fuit mihi Venetie non tectum modo ac mensa, verum etiam cubiculum et lectus communis".

38) The text was rediscovered in Paris in 1945 in the codex Parisinus Latinus 3461.

39) Franz Bierlaire, Erasme et ses Colloques (Geneva, 1977), 111, refers to Allen, ed., Opus epistolarum Desiderii Erasmi, 1717, 1. 33; 2329, 1. 106. See further, e.g., the Acta Academiae Lovaniensis contra Lutherum, ed. by Wallace K. Ferguson, Erasmi Opuscula
} 
In August 1525, then, it is to this Aleandro that the Venetian printers dedicate the fourth volume of their Galen edition. This is same month of the same year in which Aleandro wrote his treatise, Racha, against Erasmus and also the same days in which Erasmus asks the Asulani to send him back the forgotten manuscript of his Adagia.

There are thus many aspects to contemplate when examining the way in which Erasmus tore apart the Aldine edition of Galen. In order to understand his criticism, one needs to consider not only the personal features of the figures involved but also view what seems to be a purely scientific debate or divergences of opinions within the historical, political and religious setting in which this episode took place.

(The Hague, 1933), 316-17. The letters calling Aleandro a Jew are Epist. 1166, 2414, 2578. 